\title{
Role of gene polymorphisms in vitamin $D$ metabolism and in multiple sclerosis
}

\author{
Aylin Elkama and Bensu Karahalil \\ Gazi University, Faculty of Pharmacy, Department of Toxicology, Ankara, Turkey
}

[Received in November 2017; Similarity Check in November 2017; Accepted in March 2018]

\begin{abstract}
Multiple sclerosis (MS) is a complex inflammatory disease of the central nervous system (CNS) resulting in neurological impairment and disability. There is evidence that adequate vitamin D levels may lower the risk of MS development. The aetiology of MS is complex and involves both genetic and environmental factors. In fact, not one but several genes are believed to lead to the disease. As for environmental factors, one of the most important risk factors is vitamin D deficiency, which, in turn, is closely related to gene polymorphisms that play a role in vitamin D metabolism and regulation. However, information about these gene polymorphisms is quite contradictory. The aim of this review is to discuss the association between some of the vitamin D-related gene variants and MS.
\end{abstract}

KEY WORDS: cytochrome P; HLA-DRB1; vitamin D receptor

Multiple sclerosis (MS) is a chronic, inflammatory, autoimmune, and demyelinating disease of the central nervous system (CNS). It is estimated that 2.1 million people have MS worldwide (1). MS is the most common neurodegenerative disorder of Caucasian 25 to 35 -year-old adults. Women are affected three times more often than men (2). It starts as an autoimmune response to myelin proteins and other unidentified antigens that results in the demyelination and dense astrogliosis in the white matter of the brain (3). It is widely believed that the culprits for early demyelination in MS are T-cell-mediated autoimmune responses and oligodendrocyte apoptosis (4). Lymphocytes infiltrate the CNS and damage myelin and axons. The resulting neurodegeneration then leads to musculoskeletal dysfunction, muscle weakness and pain, visual problems, severe disability, and eventually death (5).

Although the aetiology of MS has not been fully elucidated, it is known that it involves an interaction between genetic, environmental, and geographical factors (6). Genetic epidemiological studies provide strong evidence that geographical localisation is highly related to MS prevalence. It increases as the latitude decreases, possibly due to low exposure to sun. Therefore, the areas with the highest risk are the north of the United States, northern Europe, Canada, southeastern Australia, and southeastern New Zealand. However, one of the countries with relatively high prevalence is also Israel (7), which suggests that geography is not the only factor contributing to the development of MS.

Correspondence to: Aylin Elkama, Gazi University, Faculty of Pharmacy, Department of Toxicology, 06330, Ankara, Turkey

E-mail: aylin.elkama@gmail.com
Low sun exposure is linked to low levels of vitamin D, and the primary source of vitamin $\mathrm{D}$ is ultraviolet $\mathrm{B}$ (UVB) light from the sun with a wavelength between 290 and $315 \mathrm{~nm}$, particularly in the summer (6).

The biologically active form of vitamin $\mathrm{D}$ is 1,25-dihydroxyvitamin D3 $(1,25(\mathrm{OH}) 2 \mathrm{D} 3)$, which is produced in several steps. A large proportion comes from the UVB-induced biotransformation of 7-dehydrocholesterol to vitamin D3, followed by two hydroxylation reactions. The first, the formation of vitamin $\mathrm{D}$ metabolite 25-hydroxyvitamin D3 25(OH)D3 occurs in the liver. The second occurs in the kidneys, where the active metabolite, $1,25(\mathrm{OH}) 2 \mathrm{D} 3$, is formed, enters the cell, and binds to the vitamin D receptor (VDR) $(6,8)$.

Most of the biological functions of vitamin D3 are mediated through VDR $(6,8)$. Monocytes, macrophages, dendritic cells, activated $\mathrm{T}$ and $\mathrm{B}$ cells are known to carry VDR on their surfaces. The major role of $1,25(\mathrm{OH}) 2 \mathrm{D} 3$ is to modulate immune response. Acting as a steroid hormone, vitamin D controls infections by enhancing the phagocytic and antibacterial activities of immune cells. Furthermore, vitamin $\mathrm{D}$ inhibits the production of pro-inflammatory cytokines (which play an important role in the development of many chronic autoimmune diseases) by stimulating regulatory T-cells and reducing T-cell proliferation. Several studies have shown that vitamin $\mathrm{D}$ helps the regulation of the immune system $(9,10)$. It is also essential for bone and calcium homeostasis (5).

Vitamin D deficiency, in turn, is believed to be associated with bone fractures, cognitive disorders, dementia, cancer, stroke, and neurodegenerative diseases, including MS $(6,11)$. The best indicator of vitamin D status is the serum $25(\mathrm{OH}) \mathrm{D}$ level. Levels below $30 \mathrm{nmol} \mathrm{L}^{-1}$ 
(12 $\mathrm{ng} \mathrm{mL} \mathrm{mL}^{-1}$ ) suggest vitamin D deficiency and 30$50 \mathrm{nmol} \mathrm{L}^{-1}\left(12-20 \mathrm{ng} \mathrm{mL}^{-1}\right)$ vitamin D insufficiency. Levels between 50 and $75 \mathrm{nmol} \mathrm{L}^{-1}\left(20-30 \mathrm{ng} \mathrm{mL}^{-1}\right)$ are considered normal (12).

However, even though epidemiological studies demonstrate low serum vitamin $\mathrm{D}$ levels and high rates of bone fractures in MS patients $(5,13)$, what stands behind this association with MS is still not clear. Some researchers suggest that vitamin D deficiency increases the risk of MS by putting the immune system in a more pro-inflammatory state (6).

Case-control studies have shown that vitamin D levels are significantly lower in people with MS than in healthy controls. In one of those studies (14), $61 \%$ of MS patients had vitamin D insufficiency. These findings raise the question of whether low vitamin D levels increase the risk of MS or is it vice versa, that MS decreases vitamin D levels. Is it, perhaps, that MS symptoms, which are exacerbated by heat, may lead to sun avoidance and result in lower vitamin D levels? Or is it that vitamin D deficiency/ insufficiency triggers MS (7)?

One argument against the first proposal is that gene variances in vitamin $\mathrm{D}$ metabolism can substantially affect serum vitamin D levels, despite sufficient UVB exposure. This is particularly true of the gene polymorphisms of drug metabolising enzymes and receptors. For example, single nucleotide polymorphisms (SNPs) of metabolising enzymes and VDR may modify how these proteins and the immune system work. In other words, polymorphisms of the genes involved in vitamin D regulation may affect susceptibility to MS development (6). And there are many gene polymorphisms of many immune receptors and drug carrier enzymes that contribute to MS.

The aim of this review was to discuss the most studied VDR and CYP450 gene polymorphisms and see how they are related to the development of MS in order to understand the functional consequences of these variations and find possible applications in risk assessment of the disease.

\section{POLYMORPHISMS OF VITAMIN D METABOLISM GENES}

\section{VDR gene polymorphisms}

VDR is an intracellular receptor that belongs to the steroid/thyroid nuclear receptor family and is found in various tissues, including brain, immune cells, and peripheral blood monocytes. The $V D R$ gene is located on $12 \mathrm{q} 13.1$, consists of 9 exons and 8 introns, and has numerous allelic variants (11). 11,25(OH)2D3 interacts with the VDR and then binds to the retinoid $\mathrm{X}$ receptor (RXR) to form a heterodimer complex. This heterodimer complex binds to the VDR response elements (VDRE) in the promoter region of the target genes in the nucleus. However, in the absence of $1,25(\mathrm{OH}) 2 \mathrm{D} 3$, VDR shuttles between the nucleus and cytoplasm instead of activating and translocating into the nucleus. Moreover, the heterodimer complex is not stable enough to bind to DNA, which results in repression of target gene transcription (15).

$V D R$ gene variants can severely affect gene activation and disturb vitamin $\mathrm{D}$ and calcium metabolism, thereby increasing the risk of autoimmune diseases such as MS (1). Considering that recent research points to VDR SNPs in the development of MS, researchers are hoping to clarify the relationship between vitamin D and MS (15). Among over 30 VDR SNPs (16) the most studied are FokI (rs 10735810), BsmI (rs 1544410), TaqI (rs731236), and ApaI (rs7975232). However, reports about the association between these four gene polymorphisms and MS risk are controversial (16-20).

BsmI (A/G substitution), TaqI (T/C substitution), and ApaI (G/T substitution) are located at the 3 ' end of the VDR gene and do not result in any structural change of the VDR protein, but there is evidence that these polymorphisms may affect VDR function through altered activation of $V D R$ expression $(1,4,15,21)$. However, only the FokI polymorphism has been associated with variations in vitamin D levels in MS patients $(8,15,17,22)$. The FokI polymorphism is located in the translation initiation site in exon 2 of the $V D R$ gene and results in two different transition initiation sites in the $V D R$. T to $\mathrm{C}$ substitution in the first translation initiation codon ATG leads to long ( $f f)$ and short $(F F)$ variants of the VDR protein (8).

\section{FokI}

The missense SNP of FokI does not to interfere with DNA binding, ligand binding, and heterodimer formation with the RXR. However, the $F$ allele has higher transcriptional activity (1). It is reported that the $f$ allele of FokI has a lower frequency in Africans than in European Caucasians and Asians (23). A case-control study (22) from the Netherlands with 212 MS patients and 289 healthy controls showed that the $F$ (shorter) allele of FokI corresponded to significantly higher levels of 1,25(OH)2D3 and significantly lower levels of $25(\mathrm{OH}) \mathrm{D} 3$ in the serum of MS patients compared to the $f$ (longer) allele ( $p=0.034$ ). Likewise, a Sicilian study with 104 MS patients and 75 healthy controls determined low serum 25(OH)D3 levels in MS patients with the $F F$ and the $F f$ genotypes compared to the MS patients with the ff genotype (8).

A study with north European Caucasians pointed to a lower expression of the ff genotype in MS patients (24). Beside the differences in transcriptional activity of the FokI variants, this polymorphism may also determine the severity of MS (15). In another study (25), in a total of 512 northern European Caucasians the $f$ allele of FokI was associated with a milder disability after the onset of MS between individuals with the Expanded Disability Status Score (EDSS) $<6$ and those with EDSS $\geq 6$. In another words, the $f$ allele was associated with reduced risk of disability. These data indicate that the VDR FokI polymorphism has 
important consequences for vitamin D metabolism in both MS and healthy control subjects. However, there are several studies that did not find any significant link between the $V D R$ polymorphism and vitamin D levels (26) or the risk of $\operatorname{MS}(2,16,17,272,16,18,24)$. An American study (17) found an association between the shorter, $F$ allele (determined in 214 women with MS) and increased transcriptional activity, but no association between MS and vitamin $\mathrm{D}$ intake among these women $(\mathrm{OR}=0.93,95 \%$ $\mathrm{CI}=0.78-1.09$ ). However, the study established a significantly lower risk of MS risk in women with the ff genotype who were taking vitamin $\mathrm{D}$ supplementation $(\mathrm{RR}=0.21,95 \%$ $\mathrm{CI}=0.06-0.78, p=0.02)$ (17). Several other studies found no association between the VDR FokI polymorphism and risk of MS, such as those conducted in Canada (28), Australia (27), Iran (1, 11), and Spain (29).

\section{BsmI}

There are several studies showing a strong association between the VDR BsmI polymorphism and MS risk (1, 11, $29)$. While in the Japanese population $A$ allele is more common, a significantly higher frequency of the homozygote $G$ allele $(G G)$ was found in $77 \mathrm{MS}$ patients compared to 95 healthy controls $(\mathrm{OR}=2.38,95 \% \mathrm{CI}=1.11-5.11, p=0.026)$ (18). In contrast, a Slovak case-control study (30) did not observe any role of BsmI allelic variants in MS susceptibility among $270 \mathrm{MS}$ patients $(58.3 \% \mathrm{G}$ allele vs $41.7 \% \mathrm{~A}$ allele) and 303 healthy controls $(57.6 \% G$ allele vs $42.4 \% A$ allele). However, with a robust analysis they found a protective effect of the $A A$ genotype against MS development when compared to the $G$ allele $(\mathrm{OR}=0.59,95 \% \mathrm{CI}=0.39-0.9$, $p=0.014$ ) (30). This protective effect is supported by the functional impact of the $G$ allele of $B s m I$ on the VDR gene expression. Another study reported that the $G$ allele of $B s m I$ decreases VDR mRNA expression (31). Therefore, the absence of the $G$ allele or the presence of the $A A$ genotype may result in normal or increased expression of $V D R$. A change in $V D R$ expression may improve receptor function and signalling and thus enhance the protective effects of vitamin D against MS (30).

An Iranian study with 113 MS patients and 112 healthy controls confirmed the protective effect of the $A A$ genotype of $B s m I$ against MS development, and also found a positive association between the $G$ allele and $\mathrm{MS}(\mathrm{OR}=1.7,95 \%$ $\mathrm{CI}=1.1-2.5, p=0.012$ ) (11). Another Iranian study (1) confirmed the association between BsmI polymorphism and MS risk. Interestingly the $A A$ genotype frequency in that study was higher in the $160 \mathrm{MS}$ patients than in the 150 healthy controls $(\mathrm{OR}=2.52,95 \% \mathrm{CI}=1.31-4.83, p=0.005$; $\mathrm{OR}=1.88,95 \% \mathrm{CI}=1.35-2.6, p=0.0002$, respectively).

In a sample population from northwestern Greece (32), no direct association was established between $B s m I$ polymorphism and MS risk or bone mineral density (BMD). However, the study reported that lower BMD and increased frequency of osteoporosis in MS patients was associated with vitamin D insufficiency. Yet, another Greek study (5) reported an association between BsmI polymorphism and bone loss in patients with MS.

\section{TaqI}

TaqI is another $V D R$ gene polymorphism studied for association with MS. In addition to reports of the strong correlation between TaqI and 25(OH)2D3 levels (22), several studies have corroborated its role in MS development. A Tunisian study (4) showed that the frequency of the $T$ allele of TaqI was significantly lower in $60 \mathrm{MS}$ patients than in 114 healthy controls, which suggests that it might protect against $\mathrm{MS}$ development $(\mathrm{OR}=0.52,95 \% \mathrm{CI}=0.3$ $0.9, p=0.012$ ). In contrast, the $C$ allele of TaqI appeared to predispose for MS. However, these findings have not been confirmed by other Caucasian Spanish (18), southern Spanish (33), Greek (32), Canadian (28), Slovak (30), and Dutch (34) studies. They all show no differences in allelic variant frequencies between MS patients and healthy controls. Huang and Xie (16) believe that this disagreement is owed to ethnicity-specific genetic variations between the studied populations. Indeed, different frequencies of the $T$ allele of TaqI have been reported for different ethnic groups, as follows: $60 \%$ in the American population (17), $63 \%$ in the Greek population (32), $65.5 \%$ in the Caucasian Spanish population (29), and $82 \%$ in the Tunisian population (4). The $C$ allele of TaqI has been reported to have a lower frequency in Asians than in Africans and European Caucasians (23). Interestingly, an Australian Caucasian study (13) with $104 \mathrm{MS}$ patients and 104 healthy controls, found that the otherwise rarer $T$ allele (allele which is cut by TaqI enzyme) was more common in MS patients than in healthy controls. The risk of MS associated with it was at least twice as high as that in non-carriers $(\mathrm{OR}=2.35,95 \%$ $\mathrm{CI}=1.29-4.27, p=0.0048)$. Furthermore, the $T$ allele of TaqI involved a three times higher risk of MS. A higher frequency of the $T$ allele of TaqI was also detected in $560 \mathrm{MS}$ cases from United Kingdom and Australia in comparison to 480 healthy controls (2).

On the other hand, TaqI and BsmI genotype distribution was significantly different in $50 \mathrm{MS}$ patients than 50 healthy controls and was associated with MS risk in the Kuwaiti population (35).

\section{ApaI}

In general population the $T$ allele of ApaI has a higher frequency in Asians and European Caucasians than in Africans (23). Findings about the association of ApaI polymorphisms with MS risk are also inconclusive. In a study of a Tunisian population (4), ApaI was not associated with MS risk; neither the allele nor the genotype frequency distribution significantly differed between MS patients and healthy controls $(p>0.05)$. A study in Slovak (30) and Kuwaiti population (35) showed similar findings. The latter 
study also found no association between ApaI and vitamin D levels.

In contrast, studies in Australian Caucasian (13) and Japanese populations (36) found a positive association between ApaI and the development of MS. In the Australian Caucasian study, the $T$ allele of ApaI was significantly associated with MS $(p<0.05)$ and there was a strong linkage disequilibrium between TaqI and ApaI variants (13). The Japanese study showed higher frequency of the $T$ allele of ApaI and the TT genotype in $77 \mathrm{MS}$ patients compared to 95 healthy controls ( $p=0.032$ and $p=0.007$, respectively) (36).

\section{$C d x-2$}

A few studies have also investigated the association between $C d x-2$ polymorphism, another SNP in the $V D R$ gene, and MS. This polymorphism causes an $A$ to $G$ substitution in the 5' UTR region of the gene and affects the function of the CDX2 transcription factor. $C d x-2$ is primarily expressed in the gut, and autoimmune diseases, including MS, are assumed to be related with gut immunity. However, the association between MS development and reduced CDX activity in the gut is uncertain (27).

An Australian study (27) with 113 MS patients and 234 healthy controls observed an increased MS risk in $G$ allele carriers exposed to sunlight for less than one hour a day ( $\mathrm{OR}=1.87 ; 95 \% \mathrm{CI}=1.07-3.28)$. Compared to the $A$ allele, the $G$ allele of $C d x-2$ was associated with a $70 \%$ reduction in transcriptional activity of the VDR gene promoter. On the other hand, the study did not find any significant association between MS risk and the $G G$ genotype versus the $A A$ genotype.

In contrast, a French study (19) conducted in MS patients and age- and sex-matched controls found no significant association between $C d x-2$ and MS, but it did establish a threefold increase in MS risk in the carriers of maternal $G$ allele and paternal $A$ allele $(\mathrm{OR}=3.13,95 \%$ $\mathrm{CI}=1.3-7.7)$. A US Caucasian study also found no significant association between MS and $C d x-2$ polymorphism ( $\mathrm{RR}=0.97,95 \% \mathrm{CI}=0.79-1.21)(17)$.

A study in middle-aged and elderly Chinese women (37), however, found an association between $C d x-2$ polymorphism and serum 25(OH)D levels and BMD.

\section{Meta-analysis of the VDR gene polymorphisms}

Meta-analysis provides more robust data than individual studies by compiling data from many studies to produce a large sample size. A recent meta-analysis (38) that included a total of $3300 \mathrm{MS}$ patients and 3194 controls from 13 case-control studies evaluated the four VDR genes, ApaI, TaqI, BsmI, and FokI and found that the homozygote $A A$ genotype of ApaI and the FF genotype of FokI were significant risk factors for MS development, but found no such association for the BsmI and TaqI polymorphisms. This meta-analysis covers a wide range of ethnic groups, including Asians (from Japan), European Caucasians (from UK, Italy, Greece, and Spain), Australians (from Tasmania), Australian Caucasians (from Queensland), Netherlands Caucasians, and Caucasian Americans (from Boston, USA). The authors reported that the data were moderately heterogeneous due to ethnic differences, study periods, and geographical latitude.

Another meta-analysis (16), which covered the same studies save for two Spanish Caucasian studies, suggested that these four $V D R$ gene polymorphisms were not associated with the risk of MS. The main reason for this result was the heterogeneity and inconsistencies between the studies, such as diagnosis of the disease, ethnic and geographical factors, sex, and different genotyping methods.

\section{Interaction between HLA-DRB1 and the VDR gene polymorphisms}

Environmental factors alone are not sufficient to explain why African American, Asian, or North American indigenous populations are more resistant to MS than Europeans, which, in turn, points to genetics (39). It is not easy to determine MS susceptibility in terms of association with one or two gene polymorphisms, since MS is a complex, polygenic heritable disorder.

However, Fernandez de Abreu et al. (19) have singled out $H L A-D R B 1$ locus as the main susceptibility region and have provided a robust association between the risk of MS and $H L A-D R B 1$ polymorphism. They have identified VDRE in the promoter region of $H L A-D R B 1$ as the binding target for VDR. Cox et al. (2) suggest that $H L A-D R B 1$ expression may be altered by $1,25(\mathrm{OH}) 2 \mathrm{D} 3$, the active form of vitamin D. In fact, they claim that $H L A-D R B 1 * 1501$ carries the highest genetic risk of MS development.

There is growing evidence of a direct interaction between $H L A-D R B 1$ and vitamin $\mathrm{D}$ as the main environmental contributor to MS. Studies $(39,40)$ suggest that the expression of $H L A-D R B 1$ in the thymus is affected by vitamin $\mathrm{D}$ deficiency in childhood, and that the underexpression of the $H L A-D R B 1 * 1501$ allele in the thymus might increase the risk of autoimmune diseases such as MS.

The MS-associated $H L A-D R B 1 * 1501$ allele is not distributed equally among ethnicities; it is high in Caucasians and low in Africans and Asians. Moreover, it is more common in women with MS (39). This finding that the association between the $H L A-D R B 1 * 1501$ allele and MS is specific for women has also been supported by Irizar et al. (33).

There are several other studies investigating the role of the $H L A-D R B 1 * 1501$ allele alone and in combination with other $V D R$ gene polymorphisms in MS susceptibility (27, $33,36,20)$. A study in Australian Caucasians (27) showed a correlation between $C d x-2$ and the $H L A-D R B 1 * 1501$ allele, with the $H L A-D R 15$ locus having the strongest 
association with MS susceptibility $(\mathrm{OR}=3.91,95 \%$ $\mathrm{CI}=2.34-6.56$ ).

A study in a Japanese population (36) found that the combination of the $T$ allele of ApaI and HLA-DRBI*1501 allele increased the risk of MS $(\mathrm{OR}=2.069)$. They also suggested that the HLA and the VDR BsmI/ApaI alleles combined may have a role in the development of the disease.

Another study of 1360 MS patients and 1677 healthy controls in Canada showed that $H L A-D R B 1 * 15$ carriers with the longer isoform $T$ allele of $F o k I$ ran the higher risk of MS ( $p=0.034)(20)$.

\section{CYP27B1 gene polymorphism}

Cytochrome P450 CYP27B1 metabolising enzyme has also been investigated in MS susceptibility due to its importance in vitamin D3 activation. This enzyme regulates the level of biologically active vitamin D and plays an important role in calcium homeostasis (41). It codes for the 25-hydroxy-vitamin D-1 alpha hydroxylase enzyme, which hydroxylates the inactive form $25(\mathrm{OH}) \mathrm{D} 3$ into its active form $1-25(\mathrm{OH}) 2 \mathrm{D} 3$. Therefore, its gene polymorphisms may alter vitamin D metabolism and, consequently, its regulatory role. Recently, the Australian and New Zealand Multiple Sclerosis Genetics Consortium (ANZ gene) reported a strong association between the $C Y P 27 B 1$ gene and MS $\left(p=5.4 \times 10^{-11}\right)(42)$. This association was confirmed by Sundqvist et al. (43) in a Swedish population (2158 MS patients and 1759 healthy controls).

In contrast, Simon et al. (17) found no such association. Instead, they observed that the combination of dietary vitamin D supplementation and the VDR FokI ff genotype could reduce the risk of MS $(p=0.02)$.

In summary, among the $V D R$ variants, the FokI $f$, BsmI A, TaqI T, and ApaI $G$ alleles have been singled out as protective against MS in most but not all studies, mostly due to ethnic differences. Furthermore, there are environmental factors to consider, along with the genetic ones. The HLA-DRBI*1501 allele is the most likely variant to be involved in MS, and its interaction with other genes involved in vitamin D metabolism has drawn scientific attention. CYP 450 gene polymorphisms have received less attention in this context and need further research.

\section{CONCLUSION}

So far, epidemiological studies have reported conflicting findings about gene polymorphisms involved in vitamin D metabolism and their association with MS. It is still unclear which and how many genes are involved in the development of MS, but it is pretty clear that research should focus on the ones that lead to vitamin D insufficiency. However, this does not complete the picture. In order to elucidate the mechanisms of MS development, other parameters participating in vitamin $D$ metabolisms should be taken into account, such as co-factors, enzyme activities, and epigenetic regulation of genes involved in vitamin D metabolism. Furthermore, MS cannot be explained by any single factor alone, whether it is environmental or genetic. Future large genome-wide studies of gene-gene and geneenvironment interactions that include other risk parameters are needed for us to be able to assess the risk of MS.

\section{Conflict of interest}

None to declare.

\section{Funding}

The authors received no specific grant from public, commercial, or not-for-profit funding agencies.

\section{REFERENCES}

1. Abdollahzadeh R, Fard MS, Rahmani F, Moloudi K, Kalani BS, Azarnezhad A. Predisposing role of vitamin D receptor (VDR) polymorphisms in the development of multiple sclerosis: A case-control study. J Neurol Sci 2016;367:14815. doi: 10.1016/j.jns.2016.05.053

2. Cox MB, Ban M, Bowden NA, Baker A, Scott RJ, LechnerScott J. Potential association of vitamin D receptor polymorphism Taq1 with multiple sclerosis. Mult Scler J 2012;18:16-22. doi: 10.1177/1352458511415562

3. Kallaur AP, Kaimen-Maciel DR, Morimoto HK, Watanabe MA, Georgeto SM, Reiche EM. Genetic polymorphisms associated with the development and clinical course of multiple sclerosis (review). Int J Mol Med 2011;28:467-79. doi: 10.3892/ijmm.2011.731

4. Ben-Selma W, Ben-Fredj N, Chebel S, Frih-Ayed M, Aouni $\mathrm{M}$, Boukadida J. Age- and gender specific effects on VDR gene polymorphisms and risk of the development of multiple sclerosis in Tunisians: a preliminary study. Int J Immunogenet 2015;42:174-81. doi: 10.1111/iji.12197

5. Lambrinoudaki I, Patikas E, Kaparos G, Armeni E, Rizos D, Thoda P, Alexandrou A, Antoniou A, Tsivgoulis G, Gatzonis S, Panoulis C, Triantafyllou N. Vitamin D receptor Bsm1 polymorphism, calcium metabolism and bone mineral density in patients with multiple sclerosis: a pilot study. Neurol Sci 2013;34:1433-9. doi: 10.1007/s10072-012-1259-7

6. Harandi AA, Harandi AA, Pakdaman H, Sahraian MA. Vitamin D and multiple sclerosis. Iran J Neurol 2014;13:1-6. PMCID: PMC3968350

7. Summerday NM, Brown SJ, Allington DR, Rivey MP. Vitamin D and multiple sclerosis: review of a possible association. J Pharm Pract 2012;25:75-84. doi: 10.1177/0897190011421839

8. Agnello L, Scazzone C, Ragonese P, Salemi G, Lo Sasso B, Schillaci R, Musso G, Bellia C, Ciaccio M. Vitamin D receptor polymorphisms and 25-hydroxyvitamin $\mathrm{D}$ in a group of Sicilian multiple sclerosis patients. Neurol Sci 2016;37:2617. doi: $10.1007 / \mathrm{s} 10072-015-2401-0$

9. Aranow C. Vitamin D and the immune system. J Investig Med 2011;59:881-6. doi: 10.231/JIM.0b013e31821b8755

10. Ben-Zvi I, Aranow C, Mackay M, Stanevsky A, Kamen DL, Marinescu LM, Collins CE, Gilkeson GS, Diamond B, Hardin JA. The impact of vitamin D on dendritic cell function 
in patients with systemic lupus erythematosus. PLoS One 2010;5(2):e9193. doi: 10.1371/journal.pone.0009193

11. Narooie-Nejad M, Moossavi M, Torkamanzehi A, Moghtaderi A, Salimi S. Vitamin D receptor gene polymorphism and the risk of multiple sclerosis in South Eastern of Iran. J Mol Neurosci 2015;56:572-6. doi: 10.1007/s12031-015-0513-x

12. Centers for Disease Control and Prevention (CDC). Second National Report on Biochemical Indicators of Diet and Nutrition in the U.S. Population; 2012 [displayed 2 March 2018]. Available at https://www.cdc.gov/nutritionreport/pdf/ nutrition_book_complete508_final.pdf

13. Tajouri L, Ovcaric M, Curtain R, Johnson MP, Griffiths LR, Csurhes P, Pender MP, Lea RA. Variation in the vitamin D receptor gene is associated with multiple sclerosis in an Australian population. J Neurogenet 2009;19:25-38. doi: $10.1080 / 01677060590949692$

14. Ozgocmen S, Bulut S, Ilhan N, Gulkesen A, Ardicoglu O, Ozkan Y. Vitamin D deficiency and reduced bone mineral density in multiple sclerosis: effect of ambulatory status and functional capacity. J Bone Miner Metab 2005;23:309-13. doi: 10.1007/s00774-005-0604-9

15. Smolders J, Peelen E, Thewissen M, Menheere P, Tervaert JWC, Hupperts R, Damoiseaux J. The relevance of vitamin $\mathrm{D}$ receptor gene polymorphisms for vitamin $\mathrm{D}$ research in multiple sclerosis. Autoimmun Rev 2009;8:621-6. doi: 10.1016/j.autrev.2009.02.009

16. Huang J, Xie ZF. Polymorphisms in the vitamin D receptor gene and multiple sclerosis risk: A meta-analysis of casecontrol studies. J Neurol Sci 2012;313:79-85. doi: 10.1016/j. jns.2011.09.024

17. Simon KC, Munger KL, Yang X, Ascherio A. Polymorphisms in vitamin $\mathrm{D}$ metabolism related genes and risk of multiple sclerosis. Mult Scler 2010;16:133-8. doi: 10.1177/1352458509355069

18. Fukazawa T, Yabe I, Kikuchi S, Sasaki H, Hamada T, Miyasaka K, Tashiro K. Association of vitamin D receptor gene polymorphism with multiple sclerosis in Japanese. J Neurol Sci 1999;166:47-52. PMID: 10465499

19. Fernandes de Abreu DA, Babron MC, Rebeix I, Fontenille C, Yaouanq J, Brassat D, Fontaine B, Clerget-Darpoux F, Jehan F, Feron F. Season of birth and not vitamin D receptor polymorphisms is a risk factor for multiple sclerosis. Mult Scler 2009;15:1146-52. doi: 10.1177/1352458509106780

20. Orton SM, Ramagopalan SV, Para AE, Lincoln MR, Handunnetthi L, Chao MJ, Morahan J, Morrison KM, Sadovnick AD, Ebers GC. Vitamin D metabolic pathway genes and risk of multiple sclerosis in Canadians. J Neurol Sci 2011;305:116-20. doi: 10.1016/j.jns.2011.02.032

21. Segal BM, Cohen JA, Antel J. Americas Committee for Treatment and Research in Multiple Sclerosis Forum 2017: Environmental factors, genetics, and epigenetics in MS susceptibility and clinical courses. Mult Scler J 2018;24:4-5. doi: $10.1177 / 1352458517737397$

22. Smolders J, Damoiseaux J, Menheere P, Tervaert JWC, Hupperts R. Fok-I vitamin D receptor gene polymorphism (rs10735810) and vitamin D metabolism in multiple sclerosis. J Neuroimmunol 2009;207:117-21. doi: 10.1016/j. jneuroim.2008.12.011

23. Uitterlinden AG, Fang Y, van Meurs JBJ, Pols HAP, van Leeuwen JPTM. Genetics and biology of vitamin D receptor polymorphisms. Gene 2004;338:143-56. doi: 10.1016/j. gene.2004.05.014
24. Partridge JM, Weatherby SJ, Woolmore JA, Highland DJ, Fryer AA, Mann CL, Boggild MD, Ollier WE, Strange RC, Hawkins CP. Susceptibility and outcome in MS: associations with polymorphisms in pigmentation-related genes. Neurology 2004;62:2323-5. doi: 10.1212/WNL.62.12.2323

25. Mamutse G, Woolmore J, Pye E, Partridge J, Boggild M, Young C, Fryer A, Hoban PR, Rukin N, Alldersea J, Strange RC, Hawkins CP. Vitamin D receptor gene polymorphism is associated with reduced disability in multiple sclerosis. Mult Scler 2008;14:1280-3. doi: 10.1177/1352458508094643

26. McGrath JJ, Saha S, Burne TH, Eyles DW. A systematic review of the association between common single nucleotide polymorphisms and 25-hydroxyvitamin D concentrations. J Steroid Biochem Mol Biol 2010;121:471-7. doi: 10.1016/j. jsbmb.2010.03.073

27. Dickinson JL, Perera DI, van der Mei AF, Ponsonby AL, Polanowski AM, Thomson RJ, Taylor BV, McKay JD, Stankovich J, Dwyer T. Past environmental sun exposure and risk of multiple sclerosis: a role for the Cdx-2 Vitamin D receptor variant in this interaction. Mult Scler 2009;15:56370. doi: $10.1177 / 1352458509102459$

28. Steckley JL, Dyment DA, Sadovnick AD, Risch N, Hayes C, Ebers GC. Genetic analysis of vitamin D related genes in Canadian multiple sclerosis patients. Canadian Collaborative Study Group. Neurology 2000;54:729-32. doi: 10.1212/ WNL.54.3.729

29. García-Martín E, Agúndez JAG, Martínez C, Benito-León J, Millán-Pascual J, Calleja P, Díaz-Sánchez M, Pisa D, Turpín-Fenoll L, Alonso-Navarro H, Ayuso-Peralta L, Torrecillas D, Plaza-Nieto JF, Jiménez-Jiménez FJ. Vitamin D3 receptor (VDR) gene rs2228570 (Fok1) and rs731236 (Taq1) variants are not associated with the risk for multiple sclerosis: results of a new study and a meta-analysis. PLoS One 2013;8(6):e65487. doi: 10.1371/journal.pone.0065487

30. Čierny D, Michalik J, Škereňová M, Kantorová E, Sivák Š, Javor J, Kurča E, Dobrota D, Lehotský J. ApaI, BsmI and TaqI VDR gene polymorphisms in association with multiple sclerosis in Slovaks. Neurol Res 2016;38:678-84. doi: 10.1080/01616412.2016.1200287

31. Morrison NA, Qi JC, Tokita A, Kelly PJ, Crofts L, Nguyen TV, Sambrook PN, Eisman JA. Prediction of bone density from vitamin D receptor alleles. Nature 1994;367:284-7. doi: 10.1038/367284a 0

32. Sioka C, Papakonstantinou S, Markoula S, Gkartziou F, Georgiou A, Georgiou I, Pelidou SH, Kyritsis AP, Fotopoulos A. Vitamin D receptor gene polymorphisms in multiple sclerosis patients in northwest Greece. J Negat Results Biomed 2011;10:3. doi: 10.1186/1477-5751-10-3

33. Irizar H, Muñoz-Culla M, Zuriarrain O, Goyenechea $\mathrm{E}$, Castillo-Triviño T, Prada A, et al. HLA-DRB1*15:01 and multiple sclerosis: a female association? Mult Scler 2012;18:569-77. doi: 10.1177/1352458511426813

34. Smolders J, Damoiseaux J, Menheere P, Tervaert JWC, Hupperts R. Association study on two vitamin D receptor gene polymorphisms and vitamin D metabolites in multiple sclerosis. Ann NY Acad Sci 2009;1173:515-20. doi: 10.1111/j.1749-6632.2009.04656.x

35. Al-Temaimi RA, Al-Enezi A, Al-Serri A, Al-Roughani R, Al-Mulla F. The association of vitamin D receptor polymorphisms with multiple sclerosis in a case-control study from Kuwait. PLoS One 2015;10(11):e0142265. doi: 10.1371/journal.pone.0142265 
36. Niino M, Fukazawa T, Yabe I, Kikuchi S, Sasaki H, Tashiro $\mathrm{K}$. Vitamin D receptor gene polymorphism in multiple sclerosis and the association with HLA class II alleles. J Neurol Sci 2000;177:65-71. PMID: 10967184

37. Ling Y, Lin H, Aleteng Q, Ma H, Pan B, Gao J, Gao X. Cdx2 polymorphism in Vitamin D receptor gene was associated with serum 25-hydroxyvitamin D levels, bone mineral density and fracture in middle-aged and elderly Chinese women. Mol Cell Endocrinol 2016;427:155-61 doi: 10.1016/j.mce.2016.03.014

38. Tizaoui K, Kaabachi W, Hamzaoui A, Hamzaoui K. Association between vitamin D receptor polymorphisms and multiple sclerosis: systematic review and meta-analysis of case-control studies. Cell Mol Immunol 2015;12:243-52. doi: 10.1038/cmi.2014.47

39. Handunnetthi L, Ramagopalan SV, Ebers GC. Multiple sclerosis, vitamin D, and HLA-DRB1*15. Neurology 2010;74:1905-10. doi: 10.1212/WNL.0b013e3181e24124
40. Ramagopalan SV, Maugeri NJ, Handunnetthi L, Lincoln MR, Orton SM, Dyment DA, DeLuca GC, Herrera BM, Chao MJ, Sadovnick AD, Ebers GC, Knight JC. Expression of Multiple Sclerosis-associated MHC Class II allele HLA-DRB1*1501 is regulated by vitamin D. PLOSGenetics 2009;5(2):e1000369. doi: 10.1371/journal.pgen.1000369

41. GeneCards Human Gene Database [displayed 12 September 2017]. Available at http://www.genecards.org/cgi-bin/ carddisp.pl?gene $=$ CYP27B1

42. Australian and New Zealand Multiple Sclerosis Genetics Consortium. Genome-wide association study identifies new multiple sclerosis loci on chromosomes 12 and 20. Nat Genet 2009;41:824-30. doi:10.1038/ng.396

43. Sundqvist E, Bäärnhielm M, Alfredsson L, Hillert J, Olsson T, Kockum I. Confirmation of association between multiple sclerosis and CYP27B1. Eur J Hum Genet. 2010;18:1349-52. doi: 10.1038/ejhg.2010.113.

\section{Uloga genskih polimorfizama u metabolizmu vitamina D i multiploj sklerozi}

Multipla skleroza složena je upalna bolest središnjeg živčanog sustava koja dovodi do neuroloških poremećaja i invalidnosti. Prema nekim istraživanjima, rizik od multiple skleroze manji je u osoba s dovoljnim razinama vitamina D. Etiologija bolesti je složena i obuhvaća nasljedne i okolišne čimbenike. Stoviše, vjeruje se da je više gena odgovorno za nastanak bolesti, a od okolišnih se čimbenika najviše izdvaja nedostatak vitamina D, što je opet povezano s genskim polimorfizmima koji su važni za regulaciju njegova metabolizma u tijelu. Dosadašnja saznanja o tim polimorfizmima i njihovoj ulozi, međutim, prilično su oprečna. Stoga je namjera ovoga preglednog članka raspraviti o mogućoj povezanosti između pojedinih varijanti gena za metabolizam vitamina $\mathrm{D}$ i nastanka multiple skleroze. 